The experiment indicated yet again how position habits may exert a spurious influence upon learning data. Another likely source of variance in savings scores-the difficulty of the discrimination task itself-was indicated.

\section{REFERENCES}

AMASSIAN, V. E. Studies in organization of a somaesthetic association area, including a unit analysis. Joumal of Neurophysiology, 1954, 17 39-58.

BENJAMIN, R. M., \& THOMPSON, R. F Differential effects of cortical lesions in infant and adult cats on roughness discrimination. Experimental Neurology, 1959, 1, 305-321.

EBNER, F. F., \& MYERS, R. E. Corpus callosum and the interhemispheric transfer of tactile learning. Joumal of Neurophysiology, 1962, 25 . 380-391.

EBNER, F. F., \& MYERS, R. E. Distribution of corpus callosum and anterior commissure in cat and raccoon. Journal of Comparative Neurology, 1965, 124, 353-366.

GAROL, H.W. The functional organization of the sensory cortex of the cat. II. Journal of Neuropathology \& Experimental Neurology, 1942a, 1, 320-329.

GAROL, H.W. Cortical origin and distribution of corpus callosum and anterior commissure in the cat. III. Journal of Neuropathology \& Experimental Neurology, 1942b, 1, 422-429.

GAZZANIGA, M. S., BOGEN, J. E., \& SPERRY, R. W. Laterality effects in somaesthesis following cerebral commissurotomy in man. Neuropsychologia, 1963, 1, 209-215.

GELLERMAN, L. W. Chance orders of alternating stimuli in visual discrimination experiments. Journal of Genetic Psychology, 1933, 42 206-208.

GLICKSTEIN, M., \& SPERRY, R.W. Intermanual somaesthetic transfer in split-brain rhesus monkeys. Journal of Comparative \& Physiological Psychology, 1960, 53, 322-327. IMBERT, M., BIGNALL, K. E., \& BUSER, P. Neocortical interconnections in the cat. Joumal of Neurophysiology, 1966, 29, 382-395.

JEEVES, M. A. Psychological studies of three cases of congenital agenesis of the corpus callosum. In E. G. Ettlinger (Ed.), Functions of the corpus callosum London: Churchill, 1965.

MEIKLE, T. H., SECHZER, J. A., \& STELLAR, E. Interhemispheric transfer of tactile CR's in corpus callosum-sectioned cats. Journal of Neurophysiology, 1962, 25, 530-543.

MYERS, R. E. Transmission of visual information within and between the hemispheres: A behavioral study. In V. B. Mountcastle (Ed.) Interhemispheric relations and cerebral dominance. Baltimore: Johns Hopkins University Press, 1962.

MYERS, R. E., \& HENSON, C. O. Role of corpus callosum in transfer of tactuokinesthetic learning in chimpanzee. Archives of Neurology, $1960,3,404-409$.

POGGIO, G. F., \& MOUNTCASTLE, V. B. A study of the functional contribution of the lemniscal and spinothalamic systems to somatic sensibility. Central nervous mechanisms in pain. Johns Hopkins Hospital Bulletin, 1960, 106 , 266-316.

STAMM, J. S., \& SPERRY, R. W. Function of corpus callosum in contralateral transfer of somaesthetic discriminations in cats. Journal of Comparative and Physiological Psychology, 1957, 50, 138-143.

NOTE

1. The authors wish to express their gratitude to Mr. D. Simpson, F.R.C.S., F.R.A.C.S. Neurosurgeon at the Adelaide Children's Hospital for his assistance with the surgical procedures used in the experiment reported above, and to Mr. R. S Tulsi, of the Anatomy Department, Adelaide University, for assistance in preparing serial sections of the brains.

\title{
An effect of yeast RNA on behavior'
}

DAMON MOUNTFORD and JOHN $R$. HESLIP, The University of Kansas, Lawrence, Kans. 66044

The rate of acquisition of a two-way avoidance task was measured for two groups of 15 rats. For 30 days prior to training and for 20 days during training, one group was injected with a yeast $R N A$ solution and the other group was injected with a saline solution. The groups did not differ on the learning task in either number of avoidance responses or on response latencies. The only observable effect of RNA was on feeding behavior. The RNA group ate significantly less food during the injections than before. The RNA group also ate significantly less food and gained significantly less weight during the injections than did the saline group.

Yeast RNA injections have been reported to facilitate the acquisition or performance of pole-jump avoidance responses (Cook et al, 1963; Corson \& Enesco, 1966; Wagner et al, 1966), to facilitate maze learning (Goren, 1965), and to increase bar-pressing on VI schedules for food reward (Brown, 1966; Solyom et al, 1968). No effect of RNA has been observed on the acquisition of visual discriminations, on shock-motivated tasks other than the pole-jump, on open-field activity, on sensitivity to shock, or on basal metabolic rate (Corson \& Enesco, 1966; Wagner et al, 1966).

Although most investigators are hesitant to apply an "enhancement of learning" interpretation to the improved performance sometimes observed following RNA injections, alternative explanations have not been consistently supported. Factors unrelated to learning, if observed, are not generally altered by the RNA injections.

The purpose of the present experiment was to observe the effects of yeast RNA injections on the acquisition of a typical two-way avoidance task. It was also hoped that measures of food and water intake and of body weight would provide some information about the general physical condition of the animals.

\section{METHOD}

The Ss were 30 male albino rats (Charles River Breeding Labs), 80 days old when the experiment began. They were housed in individual cages with free access to food (Purina Lab Chow) and water. Food and water intake were measured daily and body weight was measured every 5 days.

After 25 days of preinjection measurements, $160 \mathrm{mg} / \mathrm{kg}$ of yeast RNA (Pabst Laboratories; $10 \%$ solution) was injected daily ( 8 a.m.) into the peritoneal cavity of 15 rats, and saline injections were given to the other 15. Measures of food and water intake and of body weight were continued for 25 days after the injections began. After 15 days of injections, each rat was given a single test for startle response to shock in a stabilometer. The injections were continued throughout the subsequent avoidance training period.

Training on a two-way avoidance task began 30 days after the injections started. The apparatus consisted of two $11 \times 11 \mathrm{in}$. compartments separated by a partition with a $4 \times 4$ in. opening which allowed the rat to move from one compartment to the other. The CS was a 15-W ceiling light which illuminated the appropriate compartment, and the UCS was a scrambled grid shock ( $2 \mathrm{~mA})$. The CS-UCS interval was $5 \mathrm{sec}$ and the UCS continued for $25 \mathrm{sec}$ before terminating. A 30-sec interval was interposed between trials. Each rat was given 10 training trials per day for 20 days ( 3 to 6 p.m.). Response latencies were obtained on each trial by switching off a clock (started with the CS onset) as the rat removed its last foot from the grid in the lighted compartment; an avoidance was recorded if foot removal occurred before the shock started, as indicated by the sound of the shock scrambler.

The response latencies and total number of avoidance responses were summarized in 20 trial blocks. Change in food and water intake from control levels was represented by "difference scores" computed by subtracting average intake over 15 preinjection days from average intake during the injections. Comparisons of "change in intake" between RNA and saline groups were also performed using these difference scores. Weight gain for each rat was simply the change in body weight over 25-day periods immediately preceding and during the injections.

\section{RESULTS AND DISCUSSION}

Figure 1 shows the mean response latency and mean number of avoidance responses 


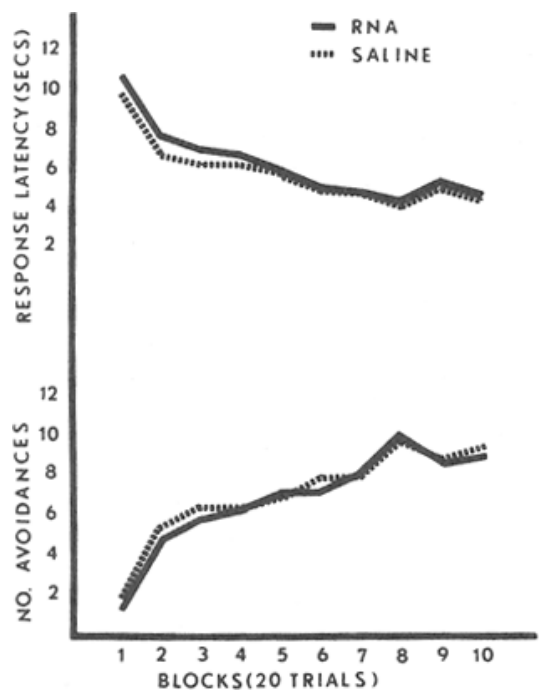

Fig. 1. Mean response latency and mean number of avoidance responses over 200 trials of training on a two-way shock-avoidance task for RNA- and saline-injected rats.

for the RNA and saline groups, in blocks of 20 trials. A two-factor (drugs and trials) analysis of variance was performed on the avoidance data, Ss nested in drugs. The trials effect was significant $(F=14.60$, df $=9 / 252, p<.01$ ), but the drugs effect and the Drugs by Trials interaction were not significant $(F=0.02$ and $0.12, \mathrm{df}=1 / 28$ and $9 / 252, p>.05)$. An identical analysis of the response latency data revealed a significant trials effect $(F=39.25$, $\mathrm{df}=9 / 252, \mathrm{p}<.01$ ), but the drugs effect and the Drugs by Trials interaction were not significant $(\mathrm{F}=0.54$ and $0.62, \mathrm{df}=1 / 28$ and $9 / 252, p>.05){ }^{2}$ These results are similar to those of other investigators (Corson \& Enesco, 1966), who report that RNA does not facilitate the acquisition of shock-motivated tasks other than the pole-jump task. These data also suggest that the effects of RNA in tasks where "facilitation of learning" is observed may be due to the influence of RNA on some aspect of performance that is unrelated to learning or retention. One possibility is that RNA may change the rat's sensitivity to shock (Wagner et al, 1966). Stabilometer measures taken before the start of avoidance training, however, showed no difference in startle responses to shock between the RNA and saline injected rats.

Figure 2 shows the mean food intake for the RNA and saline groups for 15 days prior to the injections and for 25 days during the injections. The change in food intake from preinjection levels was tested within each group. There was a significant decrease in food intake in the RNA injected group $(t=7.92, d f=14, p<.005)$, but there was no change in intake for the saline group $(t=0.54$, df $=14, p>.05)$. There was a significant difference in the change in food intake from control levels between the RNA and saline groups $(t=7.26, d f=28$, $p<.005)$. Each postinjection block of 5 days showed a significant difference between the RNA and saline groups on change in food intake (all $p<.05$ ). There were no significant differences in water intake between the RNA and saline groups.

The change in food intake during the injections also appeared to alter the rate of gain in body weight (Fig. 2). The gain in body weight for the RNA group during the 25 days of injections was significantly lower than the gain in body weight attained by the saline group $(t=5.16, d f=28, p<.005)$. The gains in body weight over 25 preinjection days did not differ between the two groups $(t=0.35, d f=28, p>.05)$.

Pathological examination of the rats in the two groups following the experiment. revealed no obvious difference in the condition of the intestinal cavity. Both groups showed scar tissue from the daily needle punctures along the midline, but no other abnormalities were observed.

The data and analyses in the present study show that RNA had no effect on the acquisition of a two-way avoidance task, but the drug did produce a decrease in food intake and a corresponding reduction in weight gain. The effects of RNA on feeding may be particularly pertinent to tasks where food served as the reward. Since decreased food intake may reflect decreased motivation for food, differences in performance between RNA and control groups on food-rewarded tasks may be reduced by the motivational effects.

\section{REFERENCES}

BROWN, H. Effect of ribonucleic acid (RNA) on the rate of lever pressing in rats. Psychological Record, 1966, 16, 173-176.

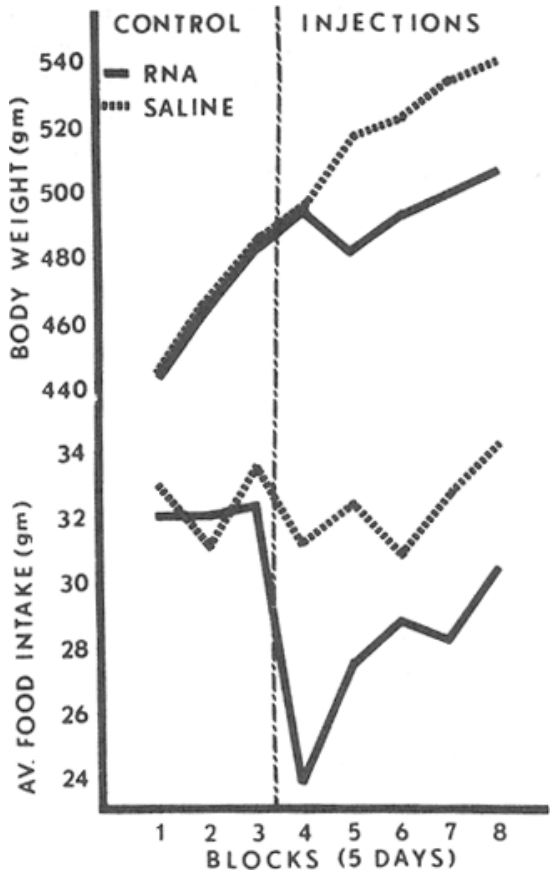

Fig. 2. Mean food intake and body weight for 15 days before injections and for 25 days during injections for the RNA- and saline-injected rats.

COOK, L., DAVIDSON, A. B., DAVIS, D. J., GREEN, H., \& FELLOWS, E. J. Ribonucleic acid: Effect on conditioned behavior in rats. Science, 1963, 141, 268-269.

CORSON, J. A., \& ENESCO, H. E. Some effects of injections of ribonucleic acid. Psychonomic Science, 1966, 5, 217-218.

GOREN, C. Ribonucleic acid: Influence on the maze-learning ability of rats. Worm Runners Digest, 1965, 7, 28-31.

SOLYOM, L., ENESCO, H. E., \& BEAULIEU, C. The effect of RNA, uric acid and caffein on conditioning and activity in rats. Journal of Psychiatric Research, 1968, 6, 175-183.

WAGNER, A. R., CARDER, J. B., \& BEATTY,W. W. Yeast ribonucleic acid: Effects on learned behavior in the rat. Psychonomic Science, 1966 , 4, 33-34.

\section{NOTES}

1. This research was supported by Grant 3340-5038 from the University of Kansas to the first author. The authors would like to thank Tom Beller and Harrel Wright, Jr., for their assistance in carrying out this experiment.

2. Latencies, rather than speed scores, were used in Fig. 1 and the analyses because the medians and ranges of latencies of the two groups were similar throughout training. 